\title{
Heritability of the queen brood post-capping stage duration in Apis mellifera mellifera $\mathrm{L}$
}

\author{
Y Le Conte 1, C Bruchou 2, K Benhamouda ${ }^{3}$, \\ C Gauthier ${ }^{1}$, JM Cornuet ${ }^{4}$ \\ 1 INRA, Station de Recherches de Zoologie et d'Apidologie; \\ 2 INRA, Station de Biométrie, BP 91, 84143 Montfavet Cedex, France; \\ 3 ITPE, Département d'Apiculture, Baba-Ali, Algiers, Algeria; \\ ${ }_{4}^{4}$ INRA-CNRS, Laboratoire de Neurobiologie Comparée des Invertébrés, BP 23, \\ 91440 Bures-sur-Yvette, France
}

(Received 8 November 1993; accepted 22 February 1994)

\begin{abstract}
Summary - The short duration of the post-capping stage of the honey bee is considered as a good trait to select for breeding honey bees resistant to Varroa jacobsoni. One way to operate is to apply this selection to queens, since this character is expressed in the 3 castes. To predict the efficiency of such a selection, we estimated: (1) the heritability of this character through daughter-queen to motherqueen regression and intra-class correlation in a population of Apis mellifera mellifera colonies in France; and (2) the regression between daughter-workers to mother-queens. The heritabilities obtained with these methods were $0.31 \pm 0.10$ and $0.22 \pm 0.25$ respectively. The worker capped period was positively correlated with the mother-queen period $(r=0.59)$, suggesting that queen selection could be efficient at obtaining workers with short capping durations. As the reduction of worker capping period can induce a decrease in the Varroa mite populations, selection for short-capping-duration queens to obtain Varroa-resistant strains is discussed.
\end{abstract}

Apis mellifera mellifera / Varroa jacobsoni / queens post-capping stage / development / selection

\section{INTRODUCTION}

At present, the use of chemicals is the only efficient way of fighting against Varroa jacobsoniOud, which is the most important threat for the honey bee (Apis mellifera $\mathrm{L}$ ) in the world. However, over time, these methods may not be suitable because of the risk of chemical contamination of the hive products, and also because of the high cost for beekeepers. Biological control methods should therefore be devised and, of these, the selection of Varroa-resistant strains is one of the best ways to control this acarine parasite. 
Two different approaches have been used to select honey bees for Varroa resistance. The first consists of collecting colonies which seem to be spontaneously resistant, without regard to the explanation of the phenomenon, and then of breeding these strains together (Kulincevic et al, 1992). The second approach consists of selecting honey bees for a particular trait (morphological, physiological or behavioral) which is thought to enhance their resistance to the mites. Among these traits is the duration of the post-capping stage of brood cells. It has been noticed (Moritz and Hänel, 1984) that about half the Varroa females cannot finish their reproductive cycle in A m capensis colonies due to the short duration of the post-capping stage in this subspecies. The influence of this parameter was confirmed through a comparative study of the development of Varroa in $A m$ capensis and $A m$ carnica worker brood (Büchler and Drescher, 1990; Moritz and Mautz, 1990). The heritability of the post-capping period in the worker brood was estimated from a sample of 3 honey-bee races ( $A$ m carnica, A $m$ scutellata and $A m$ capensis) to be 0.8 (Moritz, 1985), from a sample of 2 races ( $A$ $m$ carnica and $A m$ mellifera) and Buckfast strains to be 0.23 (Büchler and Drescher, 1990), and from North-American strain samples to be 0.61 (Harbo, 1992). The variability of this character has been observed in the worker brood of other honey-bee races (Schousboe, 1986; Le Conte and Cornuet, 1988) and therefore may be a good candidate for the indirect selection for Varroa resistance in honey bees. The duration of the post-capping stage can be measured in any caste, but selecting for that character in a sterile caste (workers) presents additional difficulties which may delay the response (Chevalet and Cornuet, 1982; Cornuet, 1987). As $A m$ mellifera queens are produced in large amounts by beekeepers in western Europe, it could be interesting to select for queens which could produce shortcapping-period workers. Furthermore, for applied and commercial purposes, it might be much easier for beekeepers to select for this character directly on the queens than on workers if there is a correlated response in both castes. A selection scheme on workers or drones would require worker or drone sample analysis or artificial insemination.

In this note, we give the genetic components of this character in a sample of honey-bee queens and estimate the regression between daughter-workers and their mother-queens, within an $A m$ mellifera population.

\section{MATERIALS AND METHODS}

Two-day-old larvae were chosen at random in 20 different colonies of $A m$ mellifera and grafted to be reared in starter-finisher hives of strong rearing colonies of hybrid stock ((ligustica $\times$ caucasica) $x$ mellifera). During the capping of the cells, observations were made every $4-6 h$ to determine the time of capping. Once capped, the cells were placed in an incubator at $34 \pm 0.5^{\circ} \mathrm{C}$ and $70 \pm 5 \%$ relative humidity. At the period of emergence of the queens, observations were made every $4 \mathrm{~h}$ to calculate the duration of the capping stage for each queen. Queens were then introduced in small nuclei and mated in natural conditions in apiaries of $A$ m mellifera.

While those queens were laying eggs, the same study was made from the larvae of 12 unrelated mother-queens. This design provides estimates of heritability through the following 2 methods: daughter-to-mother regression (Kempthorne and Tandon, 1953) and variance component analysis (Falconer, 1981; Moritz et al, 1987). The heritability is twice the mother-daughter regression coefficient. For variance component estimation, an analysis of variance was performed according to the following statistical model:

$$
Y_{i j k}=\mu+M_{i}+R_{j}+C_{i j}+Z_{i j k}
$$

where $Y_{i j k}=$ duration of the post capping stage of the $k$ th daughter queen of the th mother queen, reared in the $t$ th colony; $\mu=$ population mean; $M_{i}=$ effect of the $t h$ mother queen; $R_{j}=$ effect of the th rearing colony; $C_{i j}=$ interaction effect of mother queen $i$ and rearing colony $j$; and $Z_{i j k}=$ 
residual effect. All the variables in the model but $\mu$ were considered as random.

The analysis of variance was performed using the general linear model procedure of the Statistical Analysis System package (SAS/STAT version 6.03, Cary, NC, USA). The sampling variances and covariances of estimators were computed through the maximum likelihood variance component estimation procedure of this package. The heritability $\left(h^{2}=V_{A} V_{P}\right)$ was calculated from the intra-class correlation coefficient $V_{M} /\left(V_{M}+V_{A}+V_{C}+V_{Z}\right)$, which is approximately equal to $2 \Phi V_{A} V_{P}$ (neglecting dominance and epistatic variance components). The coefficient $\Phi$, which is the average coefficient of coancestry between 2 sister-queens, is equal to $(2+f) / 8 f$, $f$ being the average effective number of drones mated to a queen (Chevalet and Cornuet, 1982). Taking $f$ equal to 6 leads to a value of $1 / 6$ for $\Phi$, and to the following relationship:

$$
h^{2}=3 V_{M} /\left(V_{M}+V_{R}+V_{C}+V_{Z}\right)
$$

The sampling variance of this estimate of $h^{2}$ was derived by an approximation through the Taylor's series (Kendall et al, 1983).

Nine queens with short capping periods and 5 with long capping periods, naturally mated, were used to study the capping duration of their related daughter-worker brood and to establish the correlation between post-capping stage of queens and workers. A sample of 35-60 cells containing 2-3-day-old worker larvae were taken from a frame of each colony and placed in a strong rearing colony. During the capping of the cells, observations were made every 4-6 h using transparent plastic sheets to individually identify each of the brood cells. Once capped, the worker brood was placed in an incubator at $34 \pm 0.5^{\circ} \mathrm{C}$ and observations were made every $4 \mathrm{~h}$ to determine the emerging time of each brood cell.

\section{RESULTS AND DISCUSSION}

The average duration of the post-capping stage of the first set of queens $(n=117)$ was $193.7 \mathrm{~h}(\mathrm{SD}=8.3)$, with a range of 20.75 h. From 12 of these queens, 107 daughter-queens were reared. Their postcapping stage lasted an average of $182.4 \mathrm{~h}$ $(S D=5.6)$, a value which is significantly lower $\left(t_{117}=6.26, P<0.001\right)$ than in the preceding generation. As mothers selected as parents of the second generation had values dispersed over the entire range of their set (fig 1), this difference is in no way the result of any selection. Clearly, it is due to environmental factors. Since the variance component attributed to the effects of rearing colonies is not significantly different from zero, these environmental factors are probably of climatic or seasonal origin, as previously discussed by Schousboe (1990).

Figure 1 presents the values of daughterqueens plotted against their mother's value. The linear regression coefficient, calculated from each daughter-queen to mother-queen, is equal to $0.156 \pm 0.047$, which leads to a heritability estimate of $0.31 \pm 0.10$. However, the daughter-queen to mother-queen regression is not significantly different from zero. Table I provides the results of the analysis of variance on daughter-queen values. The estimation of the heritability by the variance components leads to $0.22 \pm 0.25$. In our experiment, there appears to be no significant effect of the rearing colonies but a significant interaction (rearing colony $x$ line). We have shown that capping is a behavioral response of nurse bees induced by pheromones produced by the larvae (Le Conte et al, 1990b). Among other possible explanations, such an interaction could be

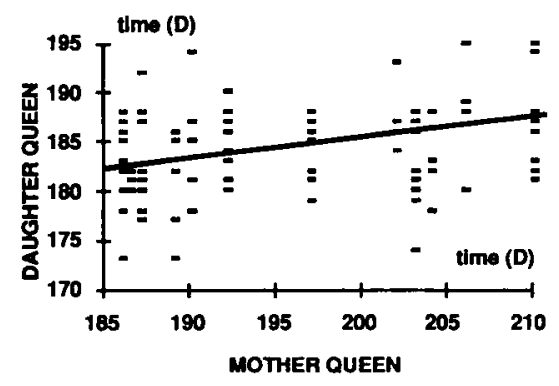

Fig 1. Daughter-queen on mother-queen regression for the duration of the post-capping stage of the queen in our $A m$ mellifera population. $Y=$ $0.2 X+146.1$. 
Table I. Estimation of the variance components for the duration of the post-capping stage of the daughter-queens in our $A m$ mellifera population.

$\begin{array}{lcccc}\text { Source of variance } & \begin{array}{c}\text { Degree of } \\ \text { freedom }\end{array} & \begin{array}{c}\text { Observed mean } \\ \text { of squares }\end{array} & \begin{array}{c}\text { Theoretical mean } \\ \text { of squares }\end{array} & \begin{array}{c}\text { Variance } \\ \text { component }\end{array} \\ \text { Rearing colony } & 5 & 27.52 & V_{Z}+1.89 V_{C}+11.90 V_{R} & V_{R}=0.48 \\ \text { Mother } & 11 & 34.86 & V_{Z}+2.16 V_{C}+7.08 V_{M} & V_{M}=1.56 \\ \text { Rearing colony x mother } & 24 & 24.98 & V_{Z}+2.44 V_{C} & V_{C}=4.18 \\ \text { Error } & 65 & 14.76 & V_{Z} & V_{Z}=14.76\end{array}$

the consequence of differential production of pheromone by larvae (line) combined with differential response by workers (rearing colony).

The average duration of the post capping stage of the worker brood $(n=535)$ was $297.3 \mathrm{~h}(\mathrm{SD}=11.6)$, with a range of $86 \mathrm{~h}$. The average worker capped period was positively correlated with the motherqueen capped period $(r=0.59)$; the slope was significantly different from zero $(P<$ 0.02) (fig 2).

An important result is that the population will respond positively to selection of queens for a shorter duration of the post-capping stage. A similar result has been found by Büchler and Drescher (1990) on worker brood $\left(h^{2}=0.23\right)$. Moritz (1985) estimated a much higher heritability $(0.83)$ than ours;

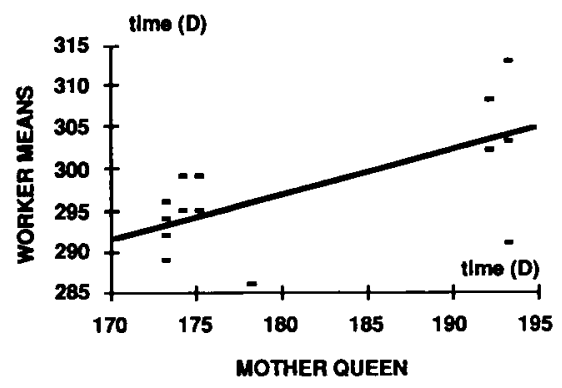

Fig 2. Mean daughter-worker on mother-queen regression for the duration of the post-capping stage in our $A m$ mellifera population. $Y=0.47 X$ +212.17 . this difference can be easily explained by the samples taken in both experiments: worker-to-worker regression with colonies of various races in his case, worker-to-queen regression with colonies of a single local population in ours.

Büchler and Drescher (1990) estimated that a $1 \mathrm{~h}$ reduction in the worker post-capping period could induce a $8.7 \%$ reduction on the Varroa mite population. In our experiment, the $20 \mathrm{~h}$ range of the capping period of the queen corresponds to a $10 \mathrm{~h}$ period range in the worker brood. From the results of Büchler and Drescher (1990), this would mean, theoretically, that the short-cappingperiod colonies (queen period $=173$ ) could have a $87 \%$ reduction on the Varroa population compared with colonies with longer worker post-capping stage period (queen period $=193$ ).

While the low daughter-queen to motherqueen regression does not seem to be encouraging for selection of that trait, there is an important worker-to-queen regression. Moritz (1985) has shown that maternal effects significantly affect the character. Moritz and Jordan (1992) have evidenced the higher effectiveness in selecting the character via drones because of a large genetic variance and the hemizygosity of the male sex. It could be interesting to select for queens producing short-capping-period workers, but a more useful method could be to use selected queens inseminated by 
short-capped-period drones. This approach could be a rapid and useful technique to obtain strains with a short post-capping stage to fight against the Varroa mite. More investigations are needed to estimate the practical benefit of such a selection. The absence of a negatively correlated response to economic traits such as the honey yield must also be checked.

A short post-capping-stage is not the only trait that can be selected for in this approach to breed honey bees resistant to Varroa. Cleaning behavior against Varroa (Peng et al, 1987) or thermic regulation of the brood (Le Conte et al, 1990a) are other characters on which similar work could be performed. Recently, Ruttner and Hänel (1992) demonstrated an active defense of Carniolian strain honey bees against Varroa mites related to the grooming behavior among the workers triggering the killing of the mites by worker mandibles. One or more of these characters could be selected with economic traits to take a important place in an 'integrated mite management' of honey bees.

\section{ACKNOWLEDGMENTS}

We thank A Paris, R Paris and D Crauser for technical assistance, BE Vaissière, $\mathrm{S}$ Walker and anonymous referees for critically revising the text. $Y$ Le Conte also wishes to thank HS Poitout for his support. This work was supported by grants from National Institute of Agricultural Research (INRA) and the French Ministry of Environment (SRETIE).

\section{Résumé - Héritabilité de la durée de la phase d'operculation du couvain de reine chez Apis mellifera mellifera. Chez} l'abeille, la période de développement pendant laquelle la cellule reste operculée est considérée comme un critère intéressant dans la sélection de souches résistantes à Varroa. Une méthode pratique consisterait à appliquer cette sélection aux reines d'abeilles, après avoir défini la corrélation entre les 3 castes pour ce caractère. Afin de prédire l'efficacité d'une telle sélection chez les reines, nous avons estimé l'héritabilité de ce caractère à travers une régression mère-fille et à travers la corrélation intra-classe d'une population d' $A m$ mellifera française. Des larves d'ouvrières d' $A m$ mellifera de $2 \mathrm{j}$, provenant de 20 colonies différentes, ont été greffées pour être élevées dans des "starter-finisher" par des colonies hybrides. La date d'operculation des cellules a été définie à travers des observations faites toutes les 4 à $6 \mathrm{~h}$. Les cellules royales operculées ont été placées en étuve à $34 \pm 0,5^{\circ} \mathrm{C}$ et à $70 \pm 5 \%$ d'humidité relative. La date d'émergence des jeunes reines a été estimée avec des observations faites toutes les $4 \mathrm{~h}$, et a permis le calcul de la durée de la période d'operculation de chaque reine. Les reines ont été introduites chacune dans un nucleus et ont été fécondées naturellement. La même étude a été réalisée à l'aide des jeunes larves de 12 de ces reines, et les résultats ont permis d'estimer l'héritabilité de ce caractère. Les valeurs de l'héritabilité, obtenues à partir de la régression fille-mère et de la corrélation intra-classe, ont été respectivement $0,31 \pm 0,10$ et $0,22 \pm 0,25$. Ces valeurs sont plus faibles que celles trouvées chez l'ouvrière par Moritz $(1985)(0,80)$ qui a utilisé un échantillon génétiquement plus large ; elles sont en accord avec celles de Büchler et Drescher (1990) $(0,23)$. La régression ouvrières-reine a ensuite été estimée pour ce critère. Des larves d'ouvrières provenant de 14 reines dont la durée d'operculation était connue ont été placées dans une même colonie éleveuse. Le moment de l'operculation des cellules, repérées à l'aide d'une feuille de plastique transparent, a été estimé grâce à des observations faites toutes les 4-6 heures. Le couvain operculé a ensuite été placé dans un incubateur pour déterminer l'émergence des ouvrières. La durée d'operculation des ouvrières a été correlée positivement avec la durée d'operculation des reines mères ( $r$ 
$=0,59, P<0,02)$. La réduction de la durée d'operculation des ouvrières entraîne une baisse des populations de Varroa dans les colonies d'abeilles (Büchler et Drescher, 1990). La sélection des reines sur ce critère peut aboutir à l'obtention d'ouvrières à durée d'operculation plus courte et donc à des colonies plus résistantes à Varroa. La sélection de reines sur ce critère peut être une méthode intéressante en particulier en la conjuguant à celle des mâles (Moritz et Jourdan, 1992) et permet d'envisager une réponse positive à la sélection de ce caractère dans notre population d'abeilles, ceci dans la mesure où la réponse n'est pas correlé négativement pour un caractère économique comme la production de miel.

\section{Apis mellifera mellifera / Varroa jacob- soni / durée d'operculation / sélection / résistance}

\section{Zusammenfassung - Heritabilität der Dauer der Verdeckelungsphase der Köni- ginnenbrut bei Apis mellifera mellifera}

L. Bei der Honigbiene wird die Dauer der Lavalentwicklung in verdeckelten Brutzellen als ein wichtiges Kriterium für die Selektion von Varroa-resistenten Linien betrachtet. Eine praktizierbare Selektionsmethode könnte möglicherweise bei den Königinnen ansetzen. Zur Bestimmung der Wirksamkeit einer solchen Königinnenselektion haben wir eine Schätzung der Heritabilität dieser Eigenschaft mit der Regression Mutter-Tochter (Königinnen- und Arbeiterinnentöchter) und der Intra-Klassen-Korrelation einer Population der französischen $A$ mellifera mellifera durchgeführt. Zweitägige Arbeiterinnenlarven aus 20 verschiedenen Völkern wurden umgelarvt und in HybridPflegevölkern aufgezogen. Der Verdeckelungszeitpunkt der Zellen wurde durch Beobachtungen im Abstand von 4-6 Stunden bestimmt. Die verdeckelten Weiselzellen wurden in einen Brutschrank bei $34 \pm$ $0,5^{\circ} \mathrm{C}$ und $70 \pm 5 \%$ Lufffeuchtigkeit gehalten.
Der Zeitpunkt des Schlupfes wurde durch Kontrollen im Abstand von 4 Stunden bestimmt. So konnte die Dauer der Verdeckelungsphase für jede Königin berechnet werden. Jede Königin wurde in ein Begattungskästchen eingeweiselt und natürlich gepaart. Die gleiche Studie wurde an jungen Larven von 12 dieser Königinnen durchgeführt. Die Werte der Heritabilität für die Verdeckelungsphase, die mit der Regression Tochter-Mutter und mit der Intra-Klassen-Korrelation berechnet wurden, betragen $0,31 \pm 0,10$ und $0,22 \pm 0,25$. Diese Werte sind kleiner als der Wert 0,80 von Moritz (1985), der somit einen größeren Effekt bei seinen genetischen Proben ermittelte. Die Werte stimmen gut mit denen von Büchler und Drescher (1990) mit 0,23 überein. Die Regression Arbeiterin-Königin sind danach ebenfalls für dieses Kriterium bestimmt worden. Arbeiterinnenlarven von 14 Königinnen, deren Verdeckelungsphase bekannt waren, wurden alle zur Aufzucht in ein einziges Volk gehängt. Der Zeitpunkt der Verdeckelung der Zellen wurde mit Hilfe einer Klarsichtfolie vermerkt. Alle 4 Stunden wurden die Zellen kontrolliert. Die verdeckelte Brutwabe wurde in einen Brutschrank gestellt, um den Schlupftermin der Arbeiterinnen zu bestimmen. Die Verdeckelungsphase der Arbeiterinnen korreliert positiv mit der der Königinnenmütter ( $r=0,59, P<0,02$ ). Die Verkürzung der Verdeckelungsphase der Arbeiterinnen bewirkt eine Verminderung der Varroapopulation in den Bienenvölkern (Büchler und Drescher, 1990). Die Selektion der Königinnen nach diesem Kriterium kann daher zu Arbeiterinnen mit verkürzter Verdeckelungsphase und damit zu Völkern mit größerer Varroa-Resistenz führen. Die Selektion auf Grund der Königinneneigenschaften ist möglicherweise eine besonders interessante Methode, wenn sie mit denen von Drohnen kombiniert werden (Moritz und Jordan, 1992). Sie deutet auf die Möglichkeit hin, einen positiven Effekt der Selektion auf eine verkürzte Verdecklungsphase in unse- 
rer Bienenpopulation zu erhalten, vorausgesetzt, daß diese Eigenschaft oder andere Reaktionen nicht negativ mit ökonomischen Eigenschaften wie der Honigproduktion korrelieren.

\section{Apis mellifera mellifera / Varroa jacob- soni / Verdecklungsphase / Selektion / Varroa-Resistanz}

\section{REFERENCES}

Büchler R, Drescher W (1990) Variance and heritability of the capped developmental stage in European Apis mellifera $L$ and its correlation with increased Varroa jacobsoni Oud infestation. J Apic Res 29, 172-176

Chevalet CL, Cornuet JM (1982) Etude théorique sur la sélection du caractère 'production de miel' chez l'abeille. I. Modèle génétique et statistique. Apidologie 13, 39-65

Cornuet JM (1987) Heritability and genetic progress for a worker character in Apis mellifera. $J$ Apic Res 26 , 165-169

Falconer DS (1981) Introduction to Quantitative Genetics, 2nd ed, Longman Group Limited, Harlow, UK

Harbo JR (1992) Breeding honey bees (Hymenoptera: Apidae) for more rapid development of larvae and pupae. J Econ Entomol 85, 2125-2130

Kendall M, Stuart A, Ord JK (1983) The Advanced Theory of Statistics, Charles Griffin and Co Ltd, London, UK, 246-247

Kempthorne O, Tandon OB (1953) The estimation of heritability by regression of offspring on parent. Biometrics 9, 90-100

Kulincevic JM, Rinderer TE, Mladjan VJ, Buco SM (1992) Five years of bi-directional genetic selection for honey bees resistant and susceptible to Varroa jacobsoni. Apidologie 23, 443-452

Le Conte Y, Cornuet JM (1988) Variability of the postcapping stage duration of the worker brood in three different races of Apis mellifera. In: Present Status of
Varroatosis in Europe and Progress in the Varroa Mite Control (R Cavalloro ed) Proc Meeting EC Experts'group, Udine (Italy), Official Publications of the European Communities, Luxembourg, 171-174

Le Conte Y, Arnold G, Desanfant P (1990a) Influence of the brood temperature and hygrometry variations on the development of the honey bee ectoparasite Varroa jacobsoni Oud (Acari: Varroinae). Environ Entomol 19, 1780-1785

Le Conte Y, Arnold G, Trouiller J, Masson C (1990b) Identification of a brood pheromone in honeybees. Naturwissenschaften 77, 334-336

Moritz FA, Hänel H (1984) Restricted development of the parasitic mite Varroa jacobsoni Oud in the Cape honeybee Apis mellifera capensis Esch $Z$ Angew Entomol 97, 91-95

Moritz FA (1985) Heritability of the postcapping stage in Apis mellifera and its relation to varroatosis resistance. $J$ Hered $76,267-270$

Moritz FA, Mautz D (1990) Development of Varroa jacobsoni in colonies of Apis mellifera capensis and Apis mellifera carnica. Apidologie 21, 53-58

Moritz FA, Jordan M (1992) Selection of resistance against Varroa jacobsoni across caste and sex in the honeybee (Apis mellifera L, Hymenoptera: Apidae). Exp Appl Acarol 16, 345-353

Moritz FA, Southwick EE, Harbo JB (1987) Genetic analysis of defensive behaviour of honeybee colonies (Apis Mellifera $\mathrm{L}$ ) in a field test. Apidologie $18,27-42$

Peng YS, Fang $Y, X u S$, Ge L (1987) The resistance mechanism of the Asian honey bee Apis cerana Fabr to an ectoparasitic mite Varroa jacobsoni Oudemans. $J$ Invertebr Pathol 49, 54-60

Ruttner $\mathrm{F}$, Hänel H (1992) Active defense against Varroa mites in a Carniolan strain of honeybee (Apis mellifera carnica Pollmann). Apidologie 23, 173-187

Schousboe C (1986) Undersogelse af forseglingsperiodens længde hos honningbiyngel (Apis mellifera $\mathrm{L}$ ) med henblik på forbedring af resistens mod Varroamiden (Varroa jacobsoni Oud). Tidsskr Planteav1 90, 293-299

Schousboe C (1990) Seasonal variation in duration of capped stage in worker bee brood Apis mellifera. Tidsskrift for Biavl 124, 50-52 